Note

\title{
Production of ethanol from mesquite [Prosopis juliflora (SW) D.C.] pods mash by Zymomonas mobilis in submerged fermentation
}

\author{
Celiane Gomes Maia da Silva ${ }^{1}$; Samara Alvachian Cardoso Andrade²; Alexandre Ricardo \\ Pereira Schuler²; Evandro Leite de Souza ${ }^{3}$; Tânia Lúcia Montenegro Stamford ${ }^{4 *}$ \\ ${ }^{1}$ UFRPE - Depto. de Ciências Domésticas, Av. Dom Manoel de Medeiros, s/n - 52171-900 - Recife, PE - Brasil. \\ ${ }^{2}$ UFPE - Depto. de Engenharia Química, Campus Universitário - 50670-901 - Recife, PE - Brasil. \\ ${ }^{3}$ UFPB - Depto. de Nutrição, Cidade Universitária, Campus I - 58059-900 - João Pessoa, PB - Brasil. \\ ${ }^{4}$ UFPE - Depto. de Nutrição. Av. Prof. Moraes Rego s/n - Cidade Universitária - 50670-901 - Recife, PE - Brasil. \\ *Corresponding author <tlmstamford@yahoo.com.br>
}

\begin{abstract}
Mesquite [Prosopis juliflora (SW) D.C.], a perennial tropical plant commonly found in Brazilian semi-arid region, is a viable raw material for fermentative processes because of its low cost and production of pods with high content of hydrolysable sugars which generate many compounds, including ethanol. This study aimed to evaluate the use of mesquite pods as substrate for ethanol production by Z. mobilis UFPEDA205 in a submerged fermentation. The fermentation was assessed for rate of substrate yield to ethanol, rate of ethanol production and efficiency of fermentation. The very close theoretical $\left(170 \mathrm{~g} \mathrm{~L}^{-1}\right)$ and experimental $\left(165 \mathrm{~g} \mathrm{~L}^{-1}\right)$ maximum ethanol yields were achieved at $36 \mathrm{~h}$ of fermentation. The highest counts of Z. mobilis UFEPEDA-205 (both close to $6 \mathrm{Log} \mathrm{cfu} \mathrm{mL}^{-1}$ ) were also noted at $36 \mathrm{~h}$. Highest rates of substrate yield to ethanol $\left(0.44 \mathrm{~g}\right.$ ethanol g glucose $\left.\mathrm{e}^{-1}\right)$, of ethanol production $\left(4.69 \mathrm{~g} \mathrm{~L}^{-1} \mathrm{~h}^{-1}\right)$ and of efficiency of fermentation $(86.81 \%)$ were found after $30 \mathrm{~h}$. These findings suggest mesquite pods as an interesting substrate for ethanol production using submerged fermentation by Z. mobilis.
\end{abstract}

Key words: renewable sources, bioconversion, fermentative parameters

\section{Produção de etanol a partir do mosto de vagens de algaroba [Prosopis juliflora (SW) D.C.] por Zymomonas mobilis em fermentação submersa}

\begin{abstract}
RESUMO: A algaroba [Prosopis juliflora (SW) D.C.] é uma planta tropical perene comumente encontrada no semi-árido brasileiro e apresenta-se como matéria-prima viável para o processo fermentativo por possuir baixo custo e para produzir vagens que contém um elevado teor de açúcares hidrolisáveis, os quais podem gerar diversos compostos, incluindo etanol. Avaliou-se o uso de vagens de algaroba como substrato para produção de etanol por Z. mobilis UFPEDA-205 por meio de fermentação submersa. O processo fermentativo foi avaliado por meio da mensuração da taxa de conversão de substrato em etanol, taxa de produção de etanol e eficiência de fermentação. Os valores muito próximos encontrados para o fornecimento máximo teórico $\left(170 \mathrm{~g} \mathrm{~L}^{-1}\right)$ e experimental $\left(165 \mathrm{~g} \mathrm{~L}^{-1}\right)$ de etanol foram alcançados após $36 \mathrm{~h}$ de fermentação. O valor de contagem experimental de Z. mobilis UFEPEDA-205 (próximo a $6 \mathrm{Log}$ cfu $\mathrm{mL}^{-1}$ ) foi encontrado após 36 h de fermentação. As mais elevadas taxas de conversão de substrato para etanol $\left(0,44 \mathrm{~g}\right.$ ethanol $\mathrm{g}$ glucose $\left.\mathrm{e}^{-1}\right)$, de produção de etanol $(4,69 \mathrm{~g}$ $\mathrm{L}^{-1} \mathrm{~h}^{-1}$ ) e de eficiência de fermentação (86,81\%) foram encontrados depois de $30 \mathrm{~h}$. Conclui-se que as vagens de algaroba apresentam potencial como substrato emergente para produção de etanol por Z. mobilis por meio de fermentação submersa.

Palavras-chave: fontes renováveis, bioconversão, parâmetros fermentativos
\end{abstract}

\section{Introduction}

Fuels obtained from renewable resources have deserved a great deal of interest during the past decades mainly due to concerns about fossil fuels depletion. Research efforts have been multiplied in the last years as a consequence of constant increasing costs and environmental impact derived from the use of crude-based fuels (Gray et al., 2006; Prasad et al., 2007).
Zymomonas mobilis is a Gram-negative, facultative anaerobic that ferments glucose, fructose, and sucrose as carbon sources (Viikari, 1998). These carbohydrates are metabolized via the same biochemical route, the Entner-Doudoroff pathway (Paula et al., 2007). Z. mobilis is a promising alternative to yeast in the synthesis of ethanol. In comparison with yeast, Z. mobilis has a higher tolerance to ethanol and better kinetic characteristics such as higher specific substrate uptake, higher ethanol synthesis rate and higher substrate yield to ethanol. 
Moreover, it has advantages for the fermentation of glucose to ethanol that include a high yield of ethanol from consumed glucose and a high specific rate of ethanol production (Joachimsthal et al., 1998; Shene and Bravo, 2001; Tano and Buzato, 2003). The metabolic activity of Z. mobilis depends on the strain and carbon source, while many by-products can be produced during the fermentation of sucrose, such as phenol, lactic acid, higher alcohols, acetaldehyde, methanol and levan (Kalneniekis et al., 2000; Borsari et al., 2006).

Prosopis juliflora (SW) D.C., Leguminosae, a popular plant known as mesquite, is native to Central and South America and has spread to North America. Mesquite has great potential for use as a multipurpose tree in different parts of the world in comparison to several native and exotic species (Kailappan et al., 2000; Deans et al., 2003). Mesquite pods present a high amount of carbohydrates (Batista et al., 2002). Pod production per tree can vary from a few $\mathrm{kg}$ to over $400 \mathrm{~kg}$ and is highly dependent on moisture availability to the plant (Riveros, 1992). In the northeast region of Brazil, mesquite trees cover 150.000 ha (Tabosa et al., 2000).

The aim of this study was to assess the use of mesquite pods as substrate for ethanol production by $Z$. mobilis UFPEDA-205 in a submerged fermentation.

\section{Material and Methods}

Strain of Z. mobilis UFEPEDA-205 used in this study was supplied by the Department of Antibiotics, Federal University of Pernambuco, Recife, Brazil. Stock cultures were kept in slopes Standard Swings and De Ley - SSDL agar (glucose 20.0; yeast extract 5.0; agar $15 \mathrm{~g} \mathrm{~L}^{-1}$ ) (Swings and De Ley, 1977) under refrigeration. For experimental assays, Z. mobilis were grown in $50 \mathrm{~mL}$ of SSDL broth at $37^{\circ} \mathrm{C}$. After $48 \mathrm{~h}$ incubation, $5 \mathrm{~mL}$ of the culture was added to flasks containing $95 \mathrm{~mL}$ of the same growth media and allowed to grow at room temperature for 24 $\mathrm{h}$ under rotation (150 $\mathrm{rpm})$.

Liquefied mash was prepared using healthy (with no infection sign) mesquite pods. Mesquite pods used in this study presented moisture 5.8; total sugars 56.5 ; reducing sugars 4.6; total fiber 7.2; proteins 9.0; fat 2.1; and ashes $0.2 \mathrm{~g} 100 \mathrm{~g}^{-1}$ (Silva et al., 2007). Pods were dried at $45^{\circ} \mathrm{C}$ for $18 \mathrm{~h}$, followed for grounding in hammer mill with a \#4 screen to get the appropriate grind size. Hydrated

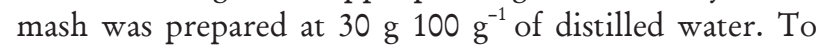
prepare the mash, ground mesquite was slowly added to distilled water in a constant agitation. After the addition of the proper ground amount, the mash was heated to $50^{\circ} \mathrm{C}$, maintained at this temperature for $1 \mathrm{~h}$ and submitted to centrifugation (3000 rpm for 15 minutes). The supernatant was vacuumed filtered using Whatman n. 1 and autoclaved at $121^{\circ} \mathrm{C}$ for $15 \mathrm{~min}$. After that, the mash was cooled to room temperature and aliquots were aseptically dispensed in sterile Erlenmeyer flasks for fermentation.
The mash used for fermentations presented total sugars (sucrose) 16.1; reducing sugars 3.99; total fiber 3.99;

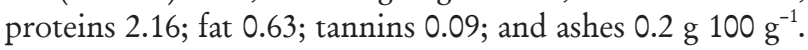
It was reported a total soluble solids value of $18^{\circ} \mathrm{Brix}$ (Silva et al., 2007).

Submerged fermentation of mesquite hydrated mash by Z. mobilis UFEPEDA-205 was analyzed. A $100-\mathrm{mL}$ aliquot of mesquite mash (added with $10 \mathrm{~g} \mathrm{~L}^{-1}\left(\mathrm{NH}_{4}\right)_{2} \mathrm{SO}_{4}$ and $\left.2 \mathrm{~g} \mathrm{~L}^{-1} \mathrm{KH}_{2} \mathrm{PO}_{4}\right)$ was aseptically distributed in sterile 250-mL Erlenmeyer flasks and inoculated with a 24 h-old culture (approximately $10^{8} \mathrm{cfu} \mathrm{mL}^{-1}$ ). The flasks were incubated at room temperature $\left(28 \pm 1^{\circ} \mathrm{C}\right)$ under static condition. During $72 \mathrm{~h}$ of fermentation, the mash was analyzed for $\mathrm{pH}$, glucose concentration, bacterial count and ethanol concentration. The fermentation was carried out in triplicate and the results were expressed as average of the parallel assays.

Kit Glicose PAP - Liquiform (Labtest Diagnóstica, Minas Gerais, Brazil) was used to measure the glucose concentration $\left(\mathrm{g} \mathrm{L}^{-1}\right)$, while the $\mathrm{pH}$ value was found using a Micronal B474 digital $\mathrm{pHmeter}$. The growth of $Z$. mobilis was evaluated by the viable cell count procedure. For this, at the pre-established periods a $100 \mu \mathrm{L}$ aliquot of the media was uniformly spread on sterile SSDL agar Petri dishes and incubated at $37^{\circ} \mathrm{C}$ for $48 \mathrm{~h}$. After the incubation period the count of viable cell was carried out and the results were expressed as Log of Colony Forming Units per $\mathrm{mL}$ (Log cfu $\left.\mathrm{mL}^{-1}\right)$.

Concentration of ethanol was determined using a gas chromatograph (HP 5890, Hewlett-Packard, Palo Alto, CA) fitted to a flame ionizer detector. A $2 \mu \mathrm{L}$-portion of the fermentation sample was injected onto a column $(30 \mathrm{~m} ; 0.25$ $\mathrm{mm}$ i.d.; $0.25 \mathrm{~lm}$, J\&W Scientific, Folsom, CA). The chromatographic conditions were as follow: sample (without dilution) injection volume $2 \mu \mathrm{L}$; hydrogen flow rate $5.0 \mathrm{~mL}$ $\mathrm{min}^{-1}$; temperature program $120^{\circ} \mathrm{C}$ (isotherm); injector temperature $100^{\circ} \mathrm{C}$; detector temperature $120^{\circ} \mathrm{C}$. The data were processed using the Millennium Computer Program (Waters Chromatograph Division, Milford, MA, USA). Analyses were performed in triplicate and the results were expressed as average of the parallel assays.

The following parameters were used for assessing the fermentative process: (i) Amount of consumed sugar: [S: - $\left(\mathrm{S}_{f}-\mathrm{S}_{0}\right)$ ], where $S$ : consumed sugar $\left(\mathrm{g}\right.$ glucose $\left.\mathrm{L}^{-1}\right) ; S_{f}$ : sugar final concentration (g glucose $\left.\mathrm{L}^{-1}\right) ; S_{0}$ : sugar initial concentration (g glucose $\mathrm{L}^{-1}$ ); (ii) Amount of produced ethanol: $\left[P:\left(P_{f}-P_{i}\right)\right]$, where $P$ : amount of produced ethanol $\left(\mathrm{g} \mathrm{L}^{-1}\right) ; P_{f}$. final ethanol concentration $\left(\mathrm{g} \mathrm{L}^{-1}\right) ; P_{i}$ : initial ethanol concentration ( $\mathrm{g} \mathrm{L}^{-1}$ ); (iii) Rate of substrate yield to ethanol: $\left[Y_{p / s}: P / S\right]$, where $Y_{p / s}$ : rate of substrate yield to ethanol (g glucose $\mathrm{g}$ ethanol ${ }^{-1}$ ); (iv) Rate of ethanol production: [PR: $P / t$ ], where $P R$ : rate of ethanol production $\left(\mathrm{g} \mathrm{L}^{-1} \mathrm{~h}^{-1}\right)$; $t$ : time of fermentation (h); (v) Efficiency of fermentation $\left(n_{p(\%)}\right)$, based on the theoretical yield according to the Gay-Lussac equation $(51.1 \mathrm{~g}$ ethanol 100 g glucose $\left.^{-1}\right):\left[n_{p(0)}: Y_{p / s} \cdot 100 / 51.1\right]$.

The data were analyzed by ANOVA using the Duncan test $(p \leq 0.05)$ and the software Statistica 6.0. 


\section{Results}

During the fermentation the amount of glucose increased up to $24 \mathrm{~h}$ (Figure 1). After $30 \mathrm{~h}$ of fermentation the glucose concentration dropped sharply and it was absent in the media after $40 \mathrm{~h}$ of fermentation. Along the $72 \mathrm{~h}$ fermentation period, the $\mathrm{pH}$ value of mesquite pods mash did not vary $(4.8-5.1)$. The maximum ethanol amount $\left(165 \mathrm{~g} \mathrm{~L}^{-1}\right)$ was achieved at $36 \mathrm{~h}$ of fermentation (Figure 1). The highest experimental count of $Z$. mobilis (close to 6 Log cfu $\mathrm{mL}^{-1}$ ) was also noted at $36 \mathrm{~h}$ (Figure 1). Highest rates of substrate yield to ethanol $\left(0.44 \mathrm{~g}\right.$ ethanol g glucose $\left.\mathrm{e}^{-1}\right)$ and efficiency of fermentation $(86.81 \%)$ were found after $30 \mathrm{~h}$ (Table 1). Ethanol productivities were $4.69 \mathrm{~g} \mathrm{~L}^{-1} \mathrm{~h}^{-1}$ and $4.56 \mathrm{~g} \mathrm{~L}^{-1} \mathrm{~h}^{-1}$ noted after $30 \mathrm{~h}$ and $36 \mathrm{~h}$ of fermentation, respectively (Figure 1). At $72 \mathrm{~h}$ the values found for all assessing parameters dropped sharply. $30 \mathrm{~h}$ was found as the shorter interval time to obtain the highest ethanol yield from the fermentation of mesquite pods mash by Z. mobilis under static condition.

\section{Discussion}

The amount of glucose dispersed in the growth medium was increasing up to $24 \mathrm{~h}$ of fermentation, although it was suppressed after $40 \mathrm{~h}$. The increasing glucose amount found in mesquite mash up to $24 \mathrm{~h}$ was probably related to a continuous hydrolysis of sucrose dispersed in the medium. Silva et al. (2007) reported that mesquite pods present high availability of sugars $(56.5 \mathrm{~g}$

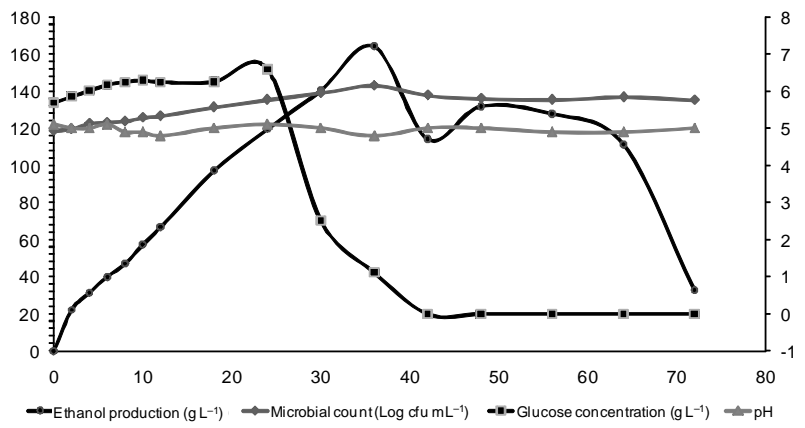

Figure 1 - Experimental values of the ethanol production and microbial count in submerged fermentation of hydrat mesquite pods mash by Z. mobilis UFEPEDA-205 under static condition. $\left.100 \mathrm{~g}^{-1}\right)$, particularly sucrose. High availability of sucrose in the growth media increases the ethanol yield by $Z$. mobilis (Favela Torres and Barati, 1988). On the other hand, small yields of ethanol are found in media rich of cellulose, inulin or starch since the bacterium is not able to hydrolyze these polymers (Shene and Bravo, 2001).

Z. mobilis presents a prominent capacity of hydrolyzing the sucrose dispersed in the growth media and rapidly metabolizes the resulting glucose as carbon source for ethanol production by the Entner-Doudoroff way (Swings and De Ley, 1977). The availability of glucose, fructose or sucrose in the growth media increases the ethanol yield by Z. mobilis (Favela Torres and Barati, 1988). Extremely high levels of glucose in a basal medium could suppress the growth of $Z$. mobilis while causing no negative effect toward the ethanol yield (Morais et al., 1993). The non-occurrence of changes at stabilization of $\mathrm{pH}$ in the mesquite mash during $72 \mathrm{~h}$ of fermentation could indicate the absence of contaminating bacteria in high number during the fermentation (Narenddranath and Power, 2004).

The three times of fermentation (30, 36 and $72 \mathrm{~h}$ ) evaluated were chosen based on the higher and smaller obtained ethanol yield. The findings suggested $30 \mathrm{~h}$ as the shorter interval time to get the highest ethanol yield from the fermentation of mesquite pods mash by $Z$. mobilis under static condition, which could possibly reduce the overall time of the process and decrease the cost for industrialization.

Aerobic cultures of Z. mobilis had higher ethanol yield from glucose with maximum theoretical values of $0.51 \mathrm{~g}$ ethanol g glucose ${ }^{-1}$ (Prasad et al., 2007). On the other hand, small yields of ethanol from glucose $(0.13$ to $0.17 \mathrm{~g}$ ethanol g glucose $\mathrm{e}^{-1}$ ) are found in anaerobic cultures (Viikari, 1998; Shene and Bravo, 2001). Tano and Buzato (2003) reported a small ethanol production $(29 \mathrm{~g}$ $\mathrm{L}^{-1}$ ) from sugar cane juice by Z. mobilis ATCC 31821 with a small substrate yield into ethanol $(0.42 \mathrm{~g}$ ethanol g glucose $^{-1}$ ) after $48 \mathrm{~h}$ under stirring (aerobic) cultivation. According to the authors, this small yield was possibly related to the amount of mineral compounds dispersed in the sugar cane juice that could inhibit the fermentation by Z. mobilis. Regarding the results of previous studies the mesquite pods hydrated mash present a higher efficiency for ethanol production in comparison to the classical substrate sugar cane juice.

Table 1 - Assessing parameters of the fermentative process for ethanol production from mesquite pods hydrated mash by Z. mobilis UFEPEDA-205 under static conditions for $72 \mathrm{~h}$.

\begin{tabular}{lccc}
\hline \multirow{2}{*}{ Assessing parameters } & \multicolumn{3}{c}{ Time of fermentation $\left(\mathrm{h}^{-1}\right)$} \\
\cline { 2 - 4 } & 30 & 36 & 72 \\
\hline$Y_{p / s}\left(\mathrm{~g} \mathrm{~g}^{-1}\right)$ & $0.44 \pm 0.02 \mathrm{a}$ & $0.35 \pm 0.03 \mathrm{~b}$ & $0.05 \pm 0.02 \mathrm{c}$ \\
$P R\left(\mathrm{~g} \mathrm{~L}^{-1} \mathrm{~h}^{-1}\right)$ & $4.69 \pm 0.02 \mathrm{a}$ & $4.56 \pm 0.04 \mathrm{~b}$ & $0.45 \pm 0.01 \mathrm{c}$ \\
$N_{p(\%)}(\%)$ & $86.81 \pm 0.02 \mathrm{a}$ & $70.37 \pm 0.01 \mathrm{~b}$ & $11.27 \pm 0.02 \mathrm{c}$ \\
\hline
\end{tabular}

Average values followed for different letter at the lines differ (Duncan, $p \mathrm{~d}$ " 0.05); $Y_{p / s:}$ rate of substrate to ethanol conversion; $P R$ : ethanol productivity; $N_{p(\%)}$ : efficiency of fermentation 
Our findings suggest mesquite pods as an emerging substrate for ethanol production using submerged fermentation by $Z$. mobilis. High levels of ethanol were produced from mesquite pods hydrated mash by submerged fermentation using Z. mobilis under static condition.

\section{References}

Batista, A.M.; Mustafa, A.F.; Mckinnon, J.J.; Kermasha, S. 2002. In situ ruminal and intestinal nutrient digestibilities of mesquite (Prosopis juliflora) pods. Animal Feed Science and Technology 100: 107-112.

Borsari, R.R.J.; Celligoi, M.A.P.C.; Buzato, J.B.; Silva, R.S.S.F. 2006. Influence of carbon source and the fermentation process on levan production by Zymomonas mobilis analyzed by the surface response. Ciência e Tecnologia de Alimentos 26: 604609.

Deans, J.D.; Diagne, O.; Nizinski, J.; Lindley, D.K.; Seck, M.; Ingleby, K.; Munro, R.C. 2003. Comparative growth, biomass production, nutrient use and soil amelioration by nitrogenfixing tree species in semi-arid Senegal. Forest Ecology and Management 176: 253-264.

Favela Torres, E.; Baratti, J. 1988. Ethanol production from wheat flour by Zymomonas mobilis. Journal of Fermentation Technology 66: 167-172.

Gray, K.A.; Zhao, L.; Emptage, M. 2006. Bioethanol. Current opinion in chemistry Biology 10: 141-146.

Joachimsthal, E.; Haggett, K.D.; Jang, J.H.; Rogers, P.L. 1998. A mutant of Zymomonas mobilis ZM4 capable of ethanol production from glucose in the presence of high acetate concentrations. Biotechnology Letters 20: 137-142.

Kailappan, R.; Gothandapani, L.; Viswanathan, R. 2000. Production of activated carbon from prosopis (Prosopis juliflora). Bioresource Technology 75: 241-243.

Kalnenieks, U.; Galinina, N.; Toma, M.M.; Poole, R.K. 2000. Cyanide inhibits respiration yet stimulates aerobic growth of Zymomonas mobilis. Microbiology 146: 1259-1266.

Morais, J.O.F.; Araújo, J.M.; Rios, E.M.; Melo, B.R. 1993. Zymomonas mobilis research in the Pernambuco Federal University. Journal of Biotechnology 31: 75-91.

Narenddranath, N.V.; Power, R. 2004. Effect of yeast inoculation rate on the metabolism of contaminating lactobacilli during fermentation of corn mash. Journal of Industrial Microbiology and Biotechnology 31: 581-584.
Prasad, S.; Singh, A.; Joshi, H.C. 2007. Ethanol as an alternative fuel from agricultural, industrial and urban residues. Resources Conservation and Recycling 50: 1-39.

Paula, V.C.; Pinheiro, I.O.; Lopes, C.E.; Calazans, G.M.T. 2007. Microwave-assisted hydrolysis of Zymomonas mobilis levan envisaging oligofructan production. Bioresource Technology 98: 2549-2556.

Riveros, F. 1992. The genus Prosopis and its potential to improve livestock production in arid and semi arid regions. p. 257-276. In: Speedy, A.; Pugliese, P., eds. Legume trees and other fodder trees as protein sources for livestock. Rome, Italy. (FAO Animal Production and Health Paper).

Shene, C.; Bravo, S. 2001. Zymomonas mobilis CP4 fed-batch fermentations of glucose-fructose mixtures to ethanol and sorbitol. Applied Microbiology and Biotechnology 57: 323-328.

Silva, C.G.M.; Melo Filho, A.B.; Pires, E.F.; Stamford, T.L.M. 2007. Physicochemical and microbiological characterization of mesquite flour (Prosopis juliflora (Sw.) DC). Ciência e Tecnologia de Alimentos 27: $733-736$ (in Portuguese, with abstract in English).

Stamford, T.L.M.; Silva, C.G.M.; Stamford. N.P. 2009. Biotechnological process for ethanol conversion from Mesquite (Prosopis juliflora). p. 481-492. In: Conference on Environment, 3,. University of Athens. Book Environmental Engineering and Management. Athens, Greece.

Swings, J.; De Ley, J. 1977. The biology of Zymomonas. Bacteriology Review 41: 1-46.

Tabosa, I.M.; Souza, J.C.; Graca, D.L.; Barbosa, J.M.; Almeida, R.N.; Riet-Correa, F. 2000. Neural vacuolation of the trigeminal nuclei in goats caused by ingestion of Prosopis juliflora (mesquite beans). Veterinary and Human Toxicology 42: 155-158.

Tano, M.S.; Buzato, J.B. 2003. Effect of the presence of initial ethanol production in sugar cane juice fermented by Zymomonas mobilis. Brazilian Journal of Microbiology 34: 242-244.

Viikari, L. 1998. Carbohydrate metabolism in Zymomonas mobilis. Review Biotechnology 7: 237-261.

Received July 30, 2009

Accepted July 26, 2010 